\title{
The optimation of farmers families' revenue the integration of Pasundan cattle and paddy farming in West Java
}

\author{
R. Tawaf*, M. Paturochman, L. Herlina, M. Sulistyati and A. Fitriani \\ Faculty of Animal Husbandry, Universitas Padjadjaran, \\ Jl. Raya Bandung - Sumedang KM 21, Sumedang - Indonesia \\ *Corresponding E-mail: rochadi@unpad.ac.id
}

Received September 29, 2017; Accepted November 09, 2017

\begin{abstract}
ABSTRAK
Tujuan penelitian ini untuk menganalisis optimalisasi penerimaan keluarga petani dengan rasio skala usaha yang paling ideal pada integrasi usahaternak sapi Pasundan dengan usahatani padi dan faktor produksi yang memberikan daya ungkit terhadap penerimaan keluarga. Responden adalah petani peternak yang melakukan integrasi usahaternak dengan usahatani padi, berjumlah 94 keluarga. Metoda penelitian adalah survey, di empat kabupaten sentra produksi sapi pasundan yang ditentukan secara purposif. Data dianalisis dengan linear programming dan fungsi produksi Cobb Douglass. Hasil analisis: (1) $\max Z=-\left(4,584,841 x_{1}+1574260\left(x_{2}+x_{3}\right)\right)+\left(6,000,000 j x_{1}+4000000\left(j x_{2}+j x_{3}\right)\right)$, persamaan ini dibatasi fungsi kendala, yaitu; tenaga kerja, transfer produk antara padi dan ternak, transfer pupuk, modal usaha musim tanam-I dan musim tanam-II. (2) $\mathrm{Y}_{\text {integrasi }}=15721319,75-72,541$ lahan $-1,317$ pupuk + 4,667 bibit $+487.765,94$ tenaga kerja usahatani $+6.339 .170,199$ nilai ternak $-935,559$ pakan + 162.618.999 tenaga kerja usaha ternak. Kesimpulan pertama, penerimaan keluarga yang optimal pada integrasi usaha ternak sapi pasundan dan padi per tahun berasal dari rasio skala usaha ternak 6,02 UT dan skala usahatani 0,5 hektar. Kedua, penerimaan integrasi usahatani ternak dapat diterangkan oleh kombinasi variabel faktor produksi luas lahan, tenaga kerja usahatani dan ternak, bibit usahatani, pakan, dan modal (ternak awal) sebesar $\mathrm{R}^{2}=87,66 \%$. Ketiga, variabel modal ternak awal berdaya ungkit terhadap penerimaan keluarga sebesar $81,52 \%$.
\end{abstract}

Kata Kunci: integrasi sapi-padi, sapi pasundan, penerimaan keluarga.

\begin{abstract}
This research aimed to analyze the revenue optimization of farmer family with ratio of the most ide al farm scale in the integration of Pasundan cattle and paddy farm, and to analyze the most leveraging pr oduction factor towards the family revenue. The respondents were 94 farmers who had integrated farming between cattle and paddy. This research used survey method in four regions purposively based o $\mathrm{n}$ Pasundan cattle centre. Data were analyzed with linear programming and production function of Cobb Douglass. The results were: (1) $\max Z=-\left(4,584,841 x_{1}+1574260\left(x_{2}+x_{3}\right)\right)+\left(6,000,000 j x_{1}+4000000\left(j x_{2}\right.\right.$ $\left.+j x_{3}\right)$ ); this function consist of constraints: labour, transfer products between cattle and paddy farm, transfer fertilizer, capital of paddy farming in planting season-I and season-II. (2) $Y_{\text {integration }}=$ $15,721,319.75-72.541$ land -1.317 fertilizer +4.667 seeds +487765.94 farming labour + 6339170.199 cattle value -935.559 feed +162618.999 cattle labour. There were some conclusions: Firs $\mathrm{t}$, the integration of Pasundan cattle and paddy farming produced the optimum family revenue/year, with ratio of 6.02 animal unit and 0.5 ha of paddy farming; Second, the production factor of agricultural land, labour, seeds, feed and capital (cattle) were explained $\left(\mathrm{R}^{2}=87.66 \%\right)$ toward the integration revenue;
\end{abstract}


Third, the variable which has the contribution to leverage the revenue was the capital of cattle $(81.52 \%)$. Keywords: integration of cattle-paddy, pasundan cattle, family revenue

\section{INTRODUCTION}

Pasundan cattle is local breed in West Java, which has been inaugurated by the Minister of Ag riculture based on the 1051/kpts/SR.120/10/2014 degree as a new clump in 2014. Pasundan cattle is historically known as 'pakidulan cattle' (sundanese) or 'sapi rancah' (sundanese) in the society (Hilmia et al., 2013). Pasundan cattle can be found in different altitudes, moreover it spread $\mathrm{s}$ across the low land and up land in West Java.

Mostly Pasundan cattle is reared by farmers, which organized subsistently and traditionally. In fact, this farm pattern has not been able to maintain the existence of Pasundan cattle in the current society. In the development, Pasundan cattle population has been decreased significantly, as there were 31,033 heads Pasundan cattle in 2016 (Arifin, 2017). The number was cruciferous with other kinds of cattle. Pure breed of Pasundan cattle population shrinks sharply every year. Now, the prediction of the population has not been more than 1,000 heads, the population decrease is mainly caused by high level of consumers' demand, whereas the maintenance is still performed traditionally (Sutarno and Setiawan, 2015).

The existence of cattle in the middle of rural communities in West Java generally functions as social status, savings, labour, fertilizer sources, and family revenue. According to Saleh et al. (2006), beef cattle farmer's income in Hamparan Perak, Deli Serdang District will deeply increase for each adding one AU (Animal Unit). Especially for paddy farmer who also do the cattle farming, this is an interdependence integrated farming, which means, the paddy farming needs organic fertilizer that produced in the livestock farming, and on the other hand, the livestock also need feed ration from the agricultural waste. This kind of integration is able to maintain and increase both the production and productivity. Integration of cattle and crops will offer benefits, i.e. increasing income both for farmers and owner of agricultural land, improving soil fertility as well as forage productivity, and to be an alternative income from selling compost and renting cattle (Elly et al., 2008).

The integration between cattle and paddy farm in West Java is generally constrained by the production factors availability, land size and cpital (Basuni et al., 2010). On the other hand, there are differences of the livestock reare pattern in West Java, especially between the low land and up land. On the low land, pasturing is more common, while on the up land the rearing livestock pattern is kept intensively. Research on integration of cattle and paddy farm to produce optimum ratio between cattle (Animal Unit) and paddy farm (ha) has not been conducted. Therefore, a research on it is very important. The objective of the study was to analyze the optimation of farmer households with the ratio of the most ideal farm scale in integration of Pasundan cattle and paddy farm.

\section{MATERIALS AND METHODS}

This research was a survey, which held on November $12^{\text {th }} 2015$ to March $10^{\text {th }} 2016$, in four different regions in West Java, which were Garut, Kuningan, Majalengka, and Sukabumi, determined purposively based on Pasundan cattle production centre as recommended by Regional Government Department of Livestock Services.

The research object was farmers who integrate the Pasundan cattle and paddy farm. The sampling technique for regions (district and sub district) determined purposively, whilst the farmers in sub district were taken by census method. The numbers of the chosen farmers were 94, which were consist of 32 farmers from Garut Region, 32 farmers from Kuningan Region, 14 farmers from Majalengka Region, and 16 farmers from Sukabumi Region. The farmers' were carrying on the paddy farm two time a year so that this research made the calculation over planting season I and planting season II.

\section{a. Linear Programming}

This analysis method was referring to Soekartawi (1995). The objective through linear $p$ rogramming in this research was to maximize the farmer's revenue with various complement farm a ctivities, and also with limited family labour resou rces. This function model that used in this researc $\mathrm{h}$ were analyzed using Maple version 15.

Objectives Function Soekartawi (1995): This research aimed to maximize the revenue of the 
farmers. In accordance with that purpose, the objectives function used was:

$\operatorname{Max} Z=$-production cost + production sales

$\operatorname{Max} Z=-\sum_{i=1}^{3} c_{i} x_{i}+\sum_{i=1}^{3} p_{i} j x_{i}$

$\operatorname{Max} Z=-\left(c_{1} x_{1}+c_{2} x_{2}+c_{3} x_{3}\right)+\left(p_{1} j x_{1}+p_{2} j x_{2}+p_{3} j x_{3}\right)$

Where:

$\mathrm{Z}$ : farmers revenues (IDR)

$\mathrm{c}_{\mathrm{i}} \quad$ : production cost (IDR)

$\mathrm{x}_{\mathrm{i}} \quad$ : output product (unit)

$\mathrm{x}_{1} \quad$ : livestock production (animal unit)

$\mathrm{x}_{2}$ : paddy farm production season I (ha)

$\mathrm{x}_{3}$ : paddy farm production season II (ha)

$\mathrm{p}_{\mathrm{i}} \quad$ : product sales (IDR)

$\mathrm{jx}_{\mathrm{i}}$ : product sales (unit)

$\mathrm{jx}_{1}$ : livestock production sales (animal unit)

$\mathrm{jx}_{2}$ : paddy farm production sales unit season I (ton)

$\mathrm{jx}_{3}$ : paddy farm production sales unit season II (ton)

Constraints Function: From both functions, Constraints function has been made to obstacle each variable.

1. Labour is one of the constraints in the farmers family in maintaining the farm integration. As the paddy farm divided in two seasons, the labour also seperated on planting season-I (rainy season) and planting season-II (dry season). This obstacle is explained through the average of labour cost in livestock and paddy farm. Therefore, the labour obstacle is the amount of each integrated farming, which smaller than the maximum cost that can be spent in a year. The equation for the labour obstacle is stated below (Soekartawi, 1995).

$$
\begin{aligned}
& \sum_{i=1}^{3} a_{i} x_{i} \leq b_{1} \\
& a_{1} x_{1}+a_{2} x_{2}+a_{3} x_{3} \leq b_{1}
\end{aligned}
$$

Where:

$a_{i} \quad$ : cost of the labour per working day in a season (IDR)

$x_{i} \quad$ : output production (unit)

$b_{i}$ : maximum cost of the labour in a year (IDR)

2. Transfer Products Between Livestock and Paddy Farm. This constraint is needed to connect one activity to another. In this research, the product transfer was used to connect the production activity to sales and consumption activity of livestock and paddy farm. The equation of plant product and livestock transfer constraint is stated below (Soekartawi, 1995).

$-\sum_{i=1}^{3} q_{i} x_{i}+\sum_{i=1}^{3} q s_{i} j x_{i} \leq 0$

$-\left(q_{1} x_{1}+q_{2} x_{2}+q_{3} x_{3}\right)+\left(q s_{1} j x_{1}+q s_{2} j x_{2}+q s_{3} j x_{3}\right) \leq 0$

Where

$\mathrm{q}_{1} \quad$ : the average of production result (unit)

$\mathrm{x}_{\mathrm{i}}$ : output production (unit)

$\mathrm{jx}_{\mathrm{i}}$ : product sales (unit)

$\mathrm{qs}_{\mathrm{i}}$ : the average of sales production result (unit)

3. Transfer Fertilizer Contribution on Paddy Farm. In this research, fertilizer $w$ used as an input in paddy farm production. The equation of fertilizer transfer obstacle (Soekartawi, 1995) was:

$$
\begin{aligned}
& \sum_{i=2}^{3} n_{i} x_{i}-n_{1} x_{1} \leq 0 \\
& n_{2} x_{2}+n_{3} x_{3}-n_{1} x_{1} \leq 0
\end{aligned}
$$

Where:

$n_{1}$ : the average of fertilizer (ton)

$n_{2}$ : the average of fertilizer used, in season-I (ton)

$n_{3}$ : the average of fertilizer used, in season-II (ton)

$x_{1}$ : the average paddy land (ha)

$x_{2}$ : the paddy land in planting season-I (ha)

$x_{3} \quad$ : the paddy land in planting season -II (ha)

4. Capital of Paddy Farming in Planting Season-I. The capital was calculated based on the average of farmer's capital that has been used. The capital obstacle is specified per planting season and stated in Indonesian Rupiah (IDR). The equation of capital obstacle (Soekartawi, 199 5) was:

$$
g_{2} x_{2}+g_{1} x_{1} \leq b_{2}
$$

Where:

$$
\begin{array}{ll}
g_{1} & : \text { average capital (IDR) } \\
g_{2} & : \text { capital season-I (IDR) } \\
b_{2} & : \text { maximum capital (IDR) } \\
x_{1} & : \text { average paddy land (ha) } \\
x_{2} & : \text { the paddy land in planting season-I (ha) }
\end{array}
$$




\section{Capital of Paddy Farming in Planting}

Season-II. The equation of capital obstacle in season II (Soekartawi, 1995) was:

Where

$$
g_{3} x_{3}+g_{1} x_{1} \leq b_{3}
$$

$$
\begin{array}{ll}
g_{1} & : \text { average capital (IDR) } \\
g_{2} & : \text { capital season-I (IDR) } \\
b_{2} & : \text { maximum capital (IDR) } \\
x_{1} & : \text { average paddy land (ha) } \\
x_{2} & : \text { the paddy land in planting season-I I(ha) }
\end{array}
$$

The optimization model in this research (Soekartawi, 1995) was:

Objectives Function:

$$
\operatorname{Max} Z=-\left(c_{1} x_{1}+c_{2} x_{2}+c_{3} x_{3}\right)+\left(p_{1} j x_{1}+p_{2} j x_{2}+p_{3} j x_{3}\right)
$$

Constraints Function:

$$
\begin{aligned}
& \text { (1) } a_{1} x_{1}+a_{2} x_{2}+a_{3} x_{3} \leq b_{1} \\
& \text { (2) }-\left(q_{1} x_{1}+q_{2} x_{2}+q_{3} x_{3}\right)+\left(q s_{1} j x_{1}+q s_{2} j x_{2}+q s_{3} j x_{3}\right) \leq 0 \\
& \text { (3) } n_{2} x_{2}+n_{3} x_{3}-n_{1} x_{1} \leq 0 \\
& \text { (4) } g_{2} x_{2}+g_{1} x_{1} \leq b_{2} \\
& \text { (5) } g_{3} x_{3}+g_{1} x_{1} \leq b_{3}
\end{aligned}
$$

\section{b. Cobb Douglass}

The Cobb Douglass analysis is used to find which production factor is the most sensitive lifting power towards the farmers family revenue, and analyzed with SPSS version 17.

Cobb Douglass function model used was :

$\mathrm{Q}_{\mathrm{t}}=\mathrm{B}\left(\mathrm{L}_{\mathrm{t}}\right)^{\alpha}\left(\mathrm{K}_{\mathrm{t}}\right)^{\beta} \quad \ldots$. ( Soekartawi, 1995; Fellipe and Adam, 2005).

Where:

$$
\begin{array}{ll}
Q_{t} & : \text { output } \\
L_{t} & : \text { labour } \\
K_{t} & : \text { capital } \\
B & : \text { constanta }
\end{array}
$$

That function was used as a guideline for the business integration as:

$\mathrm{Y}_{\mathrm{t}}=\mathrm{B}(\mathrm{LP})^{\mathrm{a}}(\mathrm{PF})^{\mathrm{b}}(\mathrm{PS})^{\mathrm{c}}(\mathrm{PFL})^{\mathrm{d}}(\mathrm{NC})^{\mathrm{e}}(\mathrm{F})^{\mathrm{f}}(\mathrm{CFL})^{\mathrm{g}}$

Where:

$$
\begin{array}{ll}
\text { LP } & \text { : Land of paddy farm(ha) } \\
\text { PF } & \text { : Paddy fertilizer (ton) } \\
\text { PS } & \text { : Paddy seeds (kilogram) } \\
\text { PFL } & \text { : Paddy farming labour (man hours) } \\
\text { NC } & \text { : Number of Cattle (Animal Unit) } \\
\text { F } & \text { : Feed (kilogram) } \\
\text { CFL } & \text { : Cattle Farm labour (man hour) }
\end{array}
$$

B : Constant

$\mathrm{Y}_{\mathrm{t}}$ : Revenue (IDR)

Before this Cobb Douglass model was used, auto correlation and linear test had been done earlier to find out that the Cobb Douglass function could be used to predict the revenue and how far the production factors play roles in the family farm revenue.

\section{RESULTS AND DISCUSSIONS}

\section{The Integration of Cattle-Paddy Farming}

Based on the research data, a simulation to find the optimum revenue of the farmer households with an ideal ratio between the amount of the livestock and the land for the paddy was performed. To measure the ratio, linear programming was used as presented in Table 1 . Table 1 shows that the cost of production activity was needed to do the production. The average of the cost that had to be spent for the farming production activity was IDR $4,584,841$, whereas the cost for paddy farming in the planting season-I as same as in the planting season-II, which was IDR 1,574,260. Roidah (2015) explained that the only difference between dry and rainy season was cost of family labour while the other cost of inputs were the same. In this research, there were no differences of every production cost as a result of anomaly season (long dry season).

The revenue was determined by quantity and price of production. The average price of the Pasundan cattle was IDR 6,000,000.00/head. This price, relatively cheaper, because the body size of Pasundan cattle was smaller than another local Indonesian beef cattle. This statement is the same with result of research by Arifin (2017), Sutarno and Setiawan (2015) and Hilmia (2013) that the Pasundan cattle has physical characteristics like as Madura and Bali cattle. The body size is relatively smaller compared with Bali Cattle, Madura cattle, Ongole Grade (PO), Simental-PO Cross or Limousin-PO Cross.

The average price of paddy in planting season-I and planting season-II was IDR $4,000,000.00 /$ ton. This price was accordance to the Indonesia Statistical Bureau's Office (2017) that the price of dry grain harvest on the field in 2016 around IDR 3,708,850.00/ton for low quality and IDR 4,205,730.00/ton for high quality. Labour cost was calculated based on working time of man hour per year. The highest value was IDR $114,300,000,00 /$ year which was taken from 
Table 1. Simulation of Livestock Ratio and Paddy Field on The Integration of Pasundan Cattle and Paddy Farming, 2016

\begin{tabular}{|c|c|c|c|c|c|}
\hline Description & Symbol & Cattle & Paddy Season-I & Paddy Season-II & Maximum (b) \\
\hline $\begin{array}{l}\text { Production: cost/year } \\
\text { (IDR) }\end{array}$ & $\mathrm{c}$ & $4,584,841$ & $1,574,260$ & $1,574,260$ & - \\
\hline $\begin{array}{l}\text { Production: sales/year } \\
\text { (IDR), per head for } \\
\text { cattle and per ton for } \\
\text { paddy season }\end{array}$ & $\mathrm{p}$ & $6,000,000$ & $4,000,000$ & $4,000,000$ & - \\
\hline Labour cost/year(IDR) & $\mathrm{a}$ & $3,600,000$ & $4,200,000$ & $4,200,000$ & $114,300,000$ \\
\hline $\begin{array}{l}\text { The average of } \\
\text { production result/year, } \\
\text { AU for cattle and ton } \\
\text { for paddy season }\end{array}$ & q & 4.80 & 1.45 & 1.28 & - \\
\hline $\begin{array}{l}\text { The average of sales } \\
\text { production result/year, } \\
\text { AU for cattle and ton } \\
\text { for paddy season }\end{array}$ & qs & 1.22 & 1.45 & 1.28 & - \\
\hline $\begin{array}{l}\text { Organic fertilizer, ton } \\
\text { for cattle and \% for } \\
\text { paddy season }\end{array}$ & $\mathrm{n}$ & 10.97 & 30 & 70 & - \\
\hline Capital (IDR) & $\mathrm{g}$ & $6,000,000$ & 100,000 & 165,000 & $114,355,000$ \\
\hline
\end{tabular}

* the unit for cattle was head and for paddy season was ton Description: $\mathrm{AU}=$ Animal Unit

19 heads (the biggest scale of cattle farms). This is accordance with the results of the research by Sundari, et al. (2009) that the labour cost on the traditional beef cattle farmers was IDR $9.478 .265,63 / 2$ heads/farm/year or equal to IDR. 90,043,523.49/19 heads/farm/year.

The average of cattle production result was 4.80 AU/year, and they sold during the Eid Al-Fitr or Eid Al-Adha and the urgent cash needs for the family. This is in accordance with Soehadji's (1994) stated that the characteristic of smallholder livestock business were its small scale of farm business, using simple technology, traditionally managed and livestock were the savings and that were sold when they need it. In this study the cattle were sold only $1.22 \mathrm{AU}$ with 1.45 tons of paddy in planting season-I, and 1.28 tons in season-II.

The organic fertilizer which was used in paddy farming was taken from cattle farming. The average of the fertilizer production in a year was around 10.97 tons. This fertilizer was composed in the cattle shed. The average of the organic fertilizer usage in the paddy farming were range around 3.29 tons to 7.68 tons. This was a very low amount of fertilizer used by the farmers. They should have been using a large amount of it because according to Sari et al. (2014) that the dosage of the cattle fertilizer for paddy ranges from 10-20 tons/hectare/year, and showing the best results paddy production at 20 ton/hectare/year.

The main capital of the integrated farming were cattle, seeds, and fertilizer which were IDR $6,000,000 /$ head, IDR $100,000 / 0.5$ ha and IDR 165,000 /season, respectively. The maximum capital that has to be spent was IDR $114,355,000$. The optimal integration ratio revealed from the research was $6.02 \mathrm{AU}: 0.5$ ha per farm. This is in alignment with Winarso (2012) that without integration there was decreasing on land tenure by the small farmer $(0,25$ ha - 0,49 ha) from $19.00 \%$ to $5.97 \%$. Those were also in line with Rizqina et al. (2011) that breakeven point of the small holder 
farm reached 6.18 AU per farm.

Based on the simulation analysis on Table 1, the optimization model of the farmer revenue was stated below:

$\operatorname{Max} \mathrm{Z}=-\left(458,481 x_{1}+1,574,260\left(x_{2}+x_{3}\right)\right)$ $+\left(6,000,000\left(j x_{2}+j x_{3}\right)\right)$

Constraints function:

1. Labour: $3,600,00 x_{1}+4,200,000 x_{2}+$ $4,200,000 x_{3} \leq 114,300,000$

2. Complementary Waste Products between livestock and paddy farm: $-\left(4.80 x_{1}+1.45 \mathrm{x}_{2}+1,28 x_{3}\right)+\left(1.22 j x_{1}+\right.$ $1.45 j x_{2}+1.28 j x_{3} \leq 0$

3. Fertilizer contribution on paddy farm : 3 $x_{2}+7 x_{3}-10.97 x_{1} \leq 0$

4. Capital of paddy farming in planting season-I : $100,000 x_{2}+600,000 \mathrm{x}_{1}$ $114,355,000 \leq 114,355,000$

5. Capital of paddy farming planting seasonII : $165,000 x_{3}+6,000,000 x_{1}+$ $114,355,000 \leq 114,355,000$

Based on the Maple 15 output above, if all of the production from cattle and paddy farming were sold, that the maximum revenue was IDR $62,011,166.11$ per year. Based on this analysis, the maximum revenue had been obtained without having to sell the harvest in second planting season. In other words, the family farmers could consume the output of season-II by themselves. Basuni et al. (2010) stated that the integration of cattle-paddy farming increase the farmer revenue as $69.45 \%$ with 5 hectares and 20 cattles scale.

From the simulation (Table 1), if the paddy production in the second planting season was consumed by the family, or if all the paddy production in the first planting season and all the livestock production were sold, it would have already been optimum to the family farmer revenue.

\section{The Influence of Production Factor of Integrated Farming towards The Revenue}

Based on the result of auto correlation analysis, the data obtained had no auto correlation and Cobb Douglass regression analysis could be done. The result was showed in Table 2.

Based on the Table 2 the regression equation was:

$\mathrm{Y}_{\text {integrasi }}=15,721,319.75-72.541$ land -1.317 fertilizer +4.667 seeds + 487,765.94 farming labour $+6,339,170.199$ cattle value - 935.559 feed $+1,626,18.999$ cattle labour.

The sign on the regression coefficient extraneous variable showed the correlation of the variables with the integration revenue. Regression coefficient for the land variable was negative, showed that there was a contradict correlation. The regression coefficient of the land was 72.541, which means for every additional land area will decrease the integration revenue as much as 72.541. This can be understood since the constraint in farming activity was the family labour, therefore the expansion of the agricultural was an optimal ratio towards the organized land area. This research according to Biniaz et al. (2014) stated that increased in the cultivation area of paddy, the marginal productivity and average labour have increased. Thus, the relation between cultivation area and labor productivity is positive. But, if labour restricted, the production of paddy

Table 2. Regression Analysis of Cobb Douglass Production Function

\begin{tabular}{lrrrrrrrr}
\hline \multicolumn{1}{c}{ Variable } & \multicolumn{1}{c}{ B } & \multicolumn{1}{c}{ Std. Error } & t. count & Sig. & Partial test & F.count & Sig. & $\mathrm{R}^{2}$ \\
\hline Constanta & $15,721,319.75$ & $2,010,985.065$ & 7.818 & 0 & & & & \\
Land & -72.541 & 186.343 & -0.389 & 0.698 & $\mathrm{~ns}$ & & & \\
Fertilizer & -1.317 & 2.127 & 0.619 & 0.538 & $\mathrm{~ns}$ & & & \\
Seeds & 4.667 & 2.928 & 1.594 & 0.115 & $\mathrm{~ns}$ & & & \\
Farming Labour & 487765.940 & 377037.056 & 1.294 & 0.200 & $\mathrm{~ns}$ & 80.1 & 0.0 & 0.877 \\
Value of Cattle & 6339170.199 & 341845.14 & 18.544 & 0.000 & $\mathrm{~s}$ & & & \\
Feed & -935.559 & 31536.056 & -0.03 & 0.976 & $\mathrm{~ns}$ & & & \\
Cattle Labour & 162618.999 & 865040.548 & 0.188 & 0.851 & $\mathrm{~ns}$ & & & \\
\hline
\end{tabular}

Description: $\mathrm{ns}=$ non significant; $\mathrm{s}=$ significant 
become decreased.

The regression coefficient for fertilizer was negative, which showed that there was a contradict correlation. The regression coefficient for fertilizer was 1.317, which means for every additional one unit fertilizer will decrease the integration revenue as much as 1.317. For fertilizer variable, the farming activity had reached the critical point condition for nonorganic fertilizer, which means the artificial fertilizer usage in farming business has to be balanced by the contribution of bigger organic fertilizer. The farmer tendency to add organic fertilizer to overcome the decreased of production is an inefficient act. Basuni et al. (2010) showed that the additional of 2 tons of organic fertilizer in paddy land can reduce the non-organic fertilizer to $57.14 \%$. Economically, this means that it can reduce the organic fertilizer up to $71.43 \%, 50 \%$ of TSP (Triple Super Phosphate), and $50 \%$ of $\mathrm{KCl}$ (Potassium Chloride) for each planting season.

The regression coefficient for the seeds variable was positive, which showed that there was a parallel correlation. The regression coefficient was 4.667 , which means for every additional one unit of seeds will increase the integration revenue as much as 4.667. This shows that the seeds production factor was able to improve the revenue.

The regression coefficient for the labour variable was positive, which showed that there was a parallel correlation. The regression coefficient for the labour was 487.765.94, which means for every additional one unit of labour will increase the integration revenue as much as 487.765.94. Based on this data, the potential of the family labour for both the paddy and the cattle farming will give a positive contribution to the family revenue. According Biniaz et al. (2014) if the number of family labor has positive sign and indicate that the value of mentioned constant inputs had positive effects on gross revenue;

The regression coefficient for the initial cattle variable was positive, which showed that there was a parallel correlation. The regression coefficient for the cattle value was 6,339,170.199, which mean for every additional one AU of cattle will increase the integration revenue as much as $6,339,170.199$. Based on this data, the cattle business looks highly prospective and influential towards the family revenue. According to Kalangi et al. (2014) stated that the total family income wa $\mathrm{s}$ affected by length of education, number of cattle owned, number of work forces in family, cattle o wnership status, and cattle rearing location . This $r$ esult appropriated with Indrayani and Hellyward (2015) on cattle integration in oil palm plantation in West Sumatra that optimal production of cattle farm breeding was reached in three years in which one cattle can produced up to 2.33 heads. Based o $\mathrm{n}$ that the family farmer got revenue around IDR 8 , 412,202.00.

The regression coefficient for the feed variable was negative, which showed that there was a contradict correlation. The regression coefficient for the feed was negative 935.559, which means for every additional one unit of feeds will decrease the integration revenue as much as 935.559. This analysis was based on the feeding calculation that was consumed at the cattle shed, whereas the time of feeding mostly done at the pasture. Therefore, the feed given at the cattle shed did not have positive effect.

In the Table $2, \mathrm{~F}$ value was 80.10 with sig. 0.000 . Because the significantly was $0.000<0.05$, it means that the land, fertilizer, seeds, farming labour, cattle value, feed, and the cattle labour had significant effect toward the integration revenue simultaneously. This was showed by the $\mathrm{R}^{2}$ value 0.877 , which mean the influence of the land, fertilizer, seeds, farming labour, cattle value, feed, and the cattle labour toward the integration revenue was $87.7 \%$, where the other $12.3 \%$ was influenced by other variables that were not explored. The correlation coefficient squared is a measure amount of variability in one variable that is explained by the other. The value range from 0 to 1 , the closer the value to 1 the strongest the model would be (Field, 2015). This implies that the model and its ratio were strong enough.

The Table 3 shows the regression analysis on the integration result. Partially, from seven extraneous variables (land size, fertilizer, seeds, farming labour, cattle value, feed, and cattle labour), there was only one variable that has a significant effect on the integration revenue, which was the cattle value. This was proven by a smaller significant value than 0.05 .

\section{Partial Influence Analysis}

The highest influence was from value of cattle, which was $81.52 \%$, whereas the lowest influence was from land and fertilizer, which were both $-0.89 \%$ (Table 3 ). The total influence of the land, fertilizer, seeds, farming labour, cattle value, feed, and the cattle labour toward the integration revenue was $87.66 \%$, whereas the other $12.34 \%$ was influenced from other variables. This was 
Table 3. Partial Influence Production Factor Variables

\begin{tabular}{lccc}
\hline \multicolumn{1}{c}{ Variable } & Beta & $\begin{array}{c}\text { Zero } \\
\text { Order }\end{array}$ & $\begin{array}{c}\text { Effect } \\
(\%)\end{array}$ \\
\hline Land & -0.020 & 0.445 & -0.89 \\
Fertilizer & -0.031 & 0.288 & -0.89 \\
Seeds & 0.072 & 0.296 & 2.13 \\
Farming Labour & 0.142 & 0.366 & 5.20 \\
Cattle value & 0.887 & 0.919 & 81.52 \\
Feed & -0.001 & 0.316 & -0.03 \\
Cattle Labour & 0.020 & 0.313 & 0.63 \\
\hline \multicolumn{4}{c}{ Total influence } \\
\hline
\end{tabular}

mainly caused by the number of cattle had the greatest leverage than any other production factor, this is in line with Rundengan et al. (2013) that every increased of number of cattle in integration farming, will increased the biggest contribution farmers revenue.

The general form of the Cobb Douglass production function is stated below.

\section{Analysis of Return To Scale (RTS)}

The RTS was $698,850.388$ calculated from $72.541-1.317+4,667+487765.94+$ $6339170.199+935.559+162,618.000)$. Based on the Cobb Douglass equation above, if the total coefficient calculated was greater than 1 (RTS $>1$ ). It means that the production process of the integration showed the "increasing return to scale" condition. In other words, the proportion of the additional production input will be responded to produce a higher proportion of integration revenue. This kind of business condition could still be developed in research area. In this position, the integration condition was highly conducive and profitable. The result is in line with Ishaq et al. (2007) that in that condition the farming is profitable.

\section{CONCLUSION}

The conclusion were 1) the integration of $\mathrm{Pa}$ sundan cattle and paddy farming in West Java pro duces the optimum family revenue per year, with $r$ atio of $6.02 \mathrm{AU}$ and 0.5 hectare (ha) of paddy far ming; 2) the production factor of agricultural land size, labour, seeds, feed ration and capital of cattle were explained $\left(\mathrm{R}^{2}=87.66 \%\right)$ toward the integration revenue, and 3) the variable which has the biggest contribution to leverage the revenue was the capital of cattle $(81.52 \%)$.

\section{ACKNOWLEDGMENT}

The authors gratefully acknowledge Rector of Universitas Padjadjaran, Dean of Animal Husbandry Faculty along with the staff for giving opportunity, fund (Contract Academic Leadership Grant number : 872/UN6.3.1/LT/2017), and facilities to do this research.

\section{REFERENCES}

Arifin, J. 2017. Konservasi Sumberdaya Genetik Sapi Pasundan di Jawa Barat. Dissertation. Fakultas Peternakan Program Pascasarjana Universitas Padjadjaran, Indonesia.

Basuni, R., Muladno, K. Cecep and Suryahadi. 20 10. Sistem integrasi padi-sapi potong di lahan sawah. J. Iptek Tanaman Pangan 5:31-48

Biniaz, A., B. Hassanpour and E. Asadi. 2014. Labor productivity and factors affecting its demand in paddy farms in KB Province Iran. J. Agric. Sci. Dev. 3:251-255

BPS. 2017. Rata-rata harga gabah menurut kualitas, komponen mutu dan HPP di tingkat petani di Indonesia, 2008-2017. Indonesia Statistical Bureau's Office.

Elly, F. H., B.M. Sinaga, U. Kuntjoro and N. Kusnadi. 2008. Pengembangan usaha ternak sapi rakyat melalui integrasi sapi-tanaman di Sulawesi Utara. J. Litbang Pertanian 27:63-68

Field, A. 2015. Discovering Statistics Using SPSS. Sage Publication Inc. London.

Ishaq, M., Farooq, A. and Farooq, U. 2007. Economies of scale in small ruminants farming in Southern North West Frontier Province-Pakistan. J. Livest. Res. for Rural Dev. 19:26-26

Indrayani, I. and J. Hellyward. 2015. Optimalisasi produksi dan maksimalisasi keuntungan usaha ternak sapi potong dengan sistem integrasi sapi-sawit di Kabupaten Dharmasraya. J. Peternakan Indonesia 17(3):187-194

Kalangi, L. S., Y. Syaukat, S. U. Kuntjoro and A. Priyanti. 2014. The Characteristics of Cattle Farmer Households and The Income of Cattle Farming Businesses in East Java. 
IOSR J. Agric. and Vet. Sci. 7:29-34

Saleh, E., S. Yunilas. and H. Yanda. 2006. Analisis Pendapatan Peternakan Sapi Potong di Kecamatan Hamparan Perak Kabupaten Deli Serdang. J. Agribisnis Peternakan. 2:36-42

Soekartawi. 1995. Analisis Usahatani. Universitas Indonesia-Press. Jakarta.

Soehadji. 1994. Membangun Peternakan Tangguh: Proses Internalisasi Pengabdian Tugas dan Inovasi Instrumental Sistem Pembangunan Peternakan Tangguh. Dissertation. Fakultas Peternakan Universitas Padjadjaran, Bandung, Indonesia.

Sutarno and Setyawan. 2015. Review: Genetic diversity of local and exotic cattle and their crossbreeding impact on the quality of Indonesian cattle. Biodiversitas. 16:327-354
Rundengan, M. L., Z. Fanani, I. Subagiyo and F. H. Elly. 2013. Integrated farming system model in South Minahasa Regency-North Sulawesi; J. Agric. and Vet. Sci. 5: 01-07

Roidah, I.S. 2015. Analisis Pendapatan Usahatani Padi Musim Hujan dan Musim Kemarau. J. Agribisnis Fakultas Pertanian Unita 11:4555

Riszqina, L., Jannah, Isbandi, E. Rianto and S.I. Santoso. 2011. Analisis Pendapatan Peternak Sapi Potong dan Sapi Bakalan Karapan di Pulau Sapudi Kabupaten Sumenep. J. Ilmu dan Teknologi Peternakan 1:188-193

Winarso, B. 2012. Dinamika pola penguasaan lahan sawah di wilayah pedesaan di Indonesia. J. Penelitian Pertanian Terapan 12:137-149 